\title{
Myth and history in Shakespeare's Rome
}

\author{
J.P. Brockbank
}

\section{(2) OpenEdition}

\section{Journals}

Electronic version

URL: https://journals.openedition.org/shakespeare/495

DOI: 10.4000/shakespeare.495

ISSN: 2271-6424

\section{Publisher}

Société Française Shakespeare

\section{Printed version}

Date of publication: 1 November 1984

Number of pages: 95-112

\section{Electronic reference}

J.P. Brockbank, "Myth and history in Shakespeare's Rome", Actes des congrès de la Société française Shakespeare [Online], 5 | 1984, Online since 01 January 2007, connection on 21 September 2021. URL: http://journals.openedition.org/shakespeare/495 ; DOI: https://doi.org/10.4000/shakespeare.495 
SOCIETE FRANÇAISE SHAKESPEARE

Actes du Congrès 1983

\section{MYTHE ET HISTOIRE}

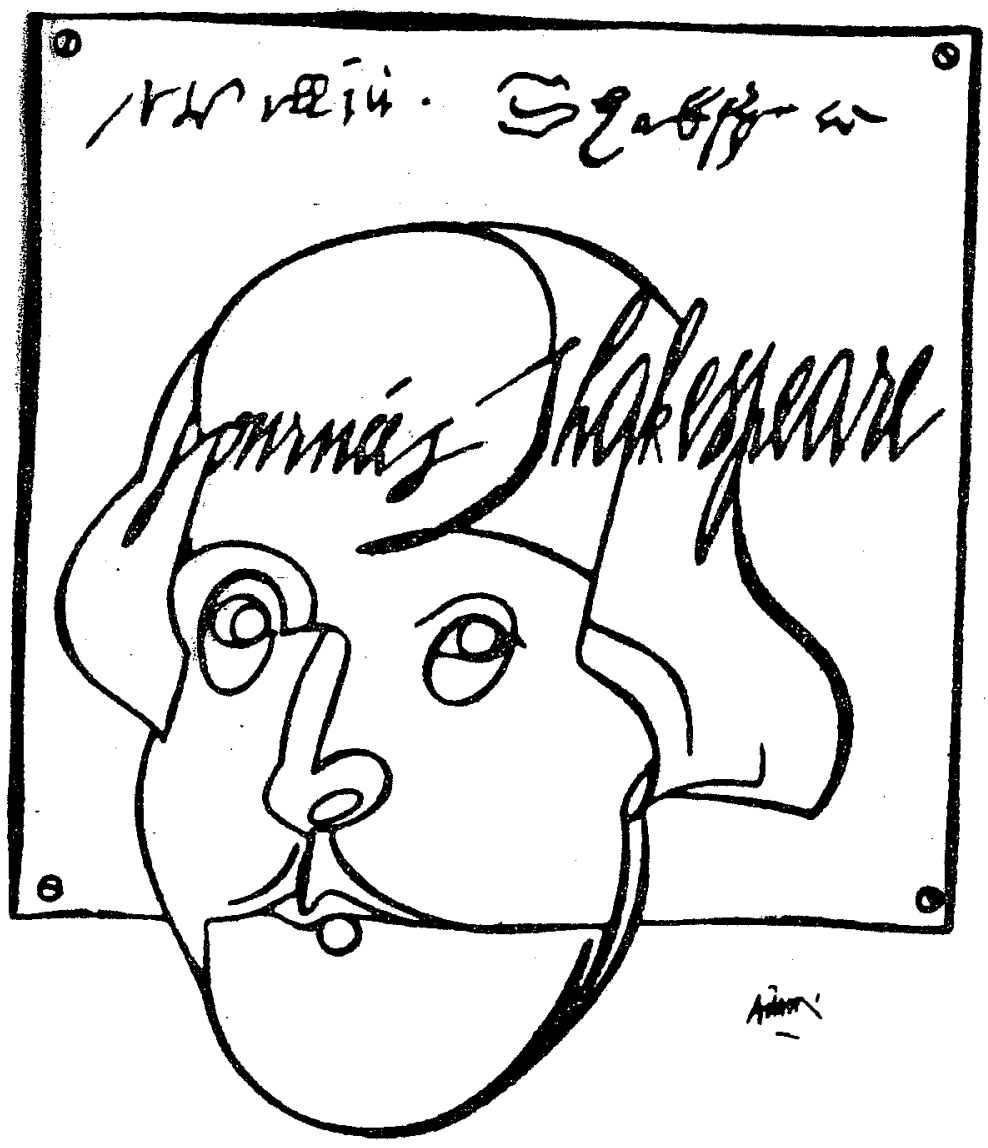

$$
\begin{array}{r}
\text { DiReCteur DE LA' PUblicatic } \\
\text { M.T. Jones-Davie }
\end{array}
$$

Publié avec le concours du Centre National de la Recherche Scientifiq

$$
\text { JEAN TOUZOT Libraire - Editeur }
$$

38, rue Saint-Sulpice 75278 PARIS CEDEX 06199 


\section{MYTH AND HISTORY IN SHAKESPEARE'S ROME}

There is a moment in the live dialogue of the past where one of Shakespeare's historical characters is speaking to another about a third, more dubiously historical character from another play. Cicero, in his Brutus is talking with Brutus about Coriolanus, in the company of the Roman historian Atticus. Cicero has reason to make some comparisons between Themistocles of Athens and Coriolanus of Rome; both, he says, were great men in their respective civilizations or states (Cicero's word is Civis); each was unjustly exiled by an ungrateful populace; each went over to the enemy, yet each relented and chose to meet a voluntary death. At this point Cicero breaks off and appeals to Atticus : «I know that you tell a different story, but allow me to believe that this was indeed the way he died» (Brutus, 42).

Atticus, whose very name declares his rational disengagement from the catastrophic history of Rome, chooses to tease Cicero a little: «As you please, for rhetoricians are allowed to distort history a little in order to give more point to their stories.» And he adds that the story Cicero believed about Themistocles was itself an invention by Clitarchus or Stratocles. Thucydides, a distinguished Athenian historian close in date to Themistocles, says he died a natural death and only «rumour» or «suspicion» put it about that he took his own life by poison. It is «the others», according to Atticus, who claim that «on sacrificing a bullock, he drank a bowl of its blood and from that draught fell dead.» "That's the sort of death», we are told, «that gave them the chance for rhetoricial and tragic embellishment, the ordinary natural death gave them no such opportunity.» And so, with strictly Attic urbanity, he approaches the end of Coriolanus : «Since it squares with your taste to make everything the same in the careers of Themistocles and Coriolanus, take the bowl too with my leave - I will even provide a sacrificial host ... in order to 
make Coriolanus a second Themistocles. » Cicero is disarmed, and undertakes in future to touch on historical matters with more caution.

Unfortunately the Liber Annalis of Atticus has not come down to us and we cannot know exactly what he said about Coriolanus's death. We may reasonably assume, however, that his account was close to that reported by Livy out of Fabius, that he lived until he was an old man and that oftentimes in his latter days he used to utter this speech, $A$ heavie case and most wretched, for an aged man to live banisht» (Holland's Livy, in Bullough, V. 505). Cicero's discourse, therefore, brings us to the point of inception of a kind of myth. Atticus, by Cicero's account the most scrupulous (religiosissimum) of Roman historians, pretends to be ready to visit the facts with a fiction in order to give the story a more tragic significance. Cicero is artful. He uses Atticus's easy-going scepticism to sustain in the dialogue the claim that rhetoric has always exercised great influence on the course of history; and not only on its course, but also on our way of narrating it - how indeed can we know one from the other ? The stories that offer to inform us about the past, take form from and give form to our present experience; thus the creative instabilities of the language take us by surprise when we attempt to talk objectively about inFORMation, SIGNificance and hiSTORY.

By the time it reached Shakespeare the Coriolanus story had been shaped by Plutarch's mentors, by Plutarch himself and by his French and English translators to an outcome that was ripe for transmutation into theatre. It was ripe not merely because the man Shakespeare found it so, but also because certain traditions of language, theatre and civilization were poised and ready for a fresh articulation and re-creation of Rome and its sustaining stories. The story of Coriolanus began to be told, perhaps 2477 years ago when, it has been rumoured, the Romans laid siege to Corioli. It was still being told a few years ago when Günter Gras wrote Die Plebeier proben den Aufstand, attending to Brecht and the work-norm riots in East Berlin; 
and John Osborne's A Place Calling Itself Rome took it into Belfast and the war-cults of our own time. A full story of the myth would take in the Roman and Greek annals, the paintings of Poussin and Tiepolo, the operas by Frederick the Great and a dozen others, the music of Beethoven and Wagner, and the scores of plays and adaptations that make up its history in the theatre. It would engage the leading motives and values of the political past of Europe - war and survival, fame, honour and prosperity, the integrity of state and populace, the class prerogatives of power, and changing notions of warrior-virtue and the properties of government. And it would show that different cultures and national traditions have, over successive generations, used the story to clarify and dramatize vital truths about their own political condition. The story of the myth might itself be made something of a myth - attributing to the muddled, dark discontinuities of the past rather more luminous order than can be found in unprocessed chronicled fact.

Each of Shakespeare's plays from Plutarch opens three perspectives of significance - into antiquity, into Shakespeare's own time, and into our own state of awareness. Coriolanus, for example, is about a critical episode in the history of the Roman city-state and of Roman democracy. But it is also about martial and political virtues as the court and the populace of Shakespeare's London understood them. And now, in the course of articulating and informing our responses to the play, we must take into account the creating and uncreating proclivities of our own perceptions. Moving in a larger Rome, but not in a larger space of consciousness, Julius Caesar is about a crisis in the history of the Republic, and Antony and Cleopatra about a critical passage in the history of the'Roman Empire. But it is still appropriate to remember that Essex, «the General of our gracious Empress» is in Henry $V$ expected to return as a «conquering Caesar» from Ireland in 1599 , to «the Mayor and all his brethren» with «the plebeians swarming at their heels»; or to recall Elizabethan or Jacobean barges that rivalled Cleopatra's in their 
splendour. Both these plays too have a continuing potency, and very varying significances, in the diverse countries and cultures of the modern world.

Amyot's preface to Plutarch's Lives contributes much to our recognition of the value and excitement of old stories and old histories told afresh. We are, he says, in the version familiar to Shakespeare :

ravished with delight and wondering, to behold the state of mankind, and the true success of things, which antiquity hath and doth bring forth from the beginning of the world, as the setting up of empires, the overthrow of monarchies, the rising and falling of kingdoms, and all things else worthy of admiration, and the same lively set forth in the fair, rich, and true table of eloquence ? And that so lively, as in the very reading of them we see our minds to be so touched by them, not as though the things were already done and past, but as though they were even then presently in doing, and we find ourselves carried away with gladness and grief through fear or hope, well near as though we were then at the doing of them.

North has followed Amyot to the point where the reader of the story is about to become the spectator of the re-created staged event. It is the point that Shakespeare reached in the late fifteen-eighties when he began to turn Holinshed's narrative into the plays of Henry VI, and ten thousand spectators, according to Thomas Nash, could imagine they beheld Talbot «fresh-bleeding». The dynamics of historical theatre are not essentially discursive or philosophic but affective and imaginative; «we are carried away with the gladness and the grief, through fear and hope» of past events, «well near as though we were then at the doing of them.»

Shakespeare's Roman plays are not merely history and myth, they are also theatrical experiences. «Gladness 
and grief», «fear and hope» are more urgently experienced and more sharply focussed upon the theatre's «table of eloquence», and they will not always answer to a rational account. While they are intensely and personally felt, the processes that shape them (often clarified in the theatre) are often obscure and impersonal - unconscious, cultural, biological - even when they find rational pretext and occasion. Thus there are truths about human consciousness and community, and about the relationship between them, which can be expressed in the languages of poetry and theatre, that can be fully expressed in no other way. The most interesting manifestations of the literary and theatrical imagination are not to be explained in terms that diminish their autonomy. Explanations derived from theories of economic history, for example, undervalue those complexities of response to money, property and power that theatre at its best anatomises; and psychological explanations are apt to neglect those large and impersonal structures and processes of society that can be expressed in the design of a play.

It is convenient to remember that Julius Caesar is likely to have been the first play performed at the opening of the first Globe theatre in 1599 and can therefore be said to mark a climactic point in the development of Shakespeare's art, in the history of theatre, and in the history of our consciousness of Rome. It offers insight into the Roman psyche and the Roman community, mediated through the renascent English language and its re-created structures, both verbal and material, of tragic theatre. The Globe was large enough to hold over two-and-a-half thousand spectators, and small enough to keep them all within easy talking-distance of its front-centre stage. It created audiences for both private and public speech; it could eavesdrop on intimate conversation and self-communing soliloquy, or it could offer platform and audience for political exhortation. By directly engaging the responses of our isolated or communal selves, the Globe play can change the relationship between them.

Shakespeare in his plays from Plutarch is very con- 
scious of that relationship; he explores it in the state and he exploits it in the theatre. In Julius Caesar Shakespeare opens pinhole perspectives into Plutarch's narrative that are at once transient and revelatory. In the three-hour traffic of the Globe stage on this occasion, Cicero, our leading meditator on myth and history, is allowed but three minutes. The distance between his response to events and Casca's is first measured in the second scene: «Did Cicero say anything ? - Ay, he spoke Greek - To what effect ? - Nay, and I tell you that, I'll ne'er look you i'th'face again. Eut those that understood him smiled at one another, and shook their heads; but, for mine own part, it was Greek to me.» Shakespeare has Casca relate the cataclysmic portents that Plutarch recalls from Strabo, but Cicero receives them with sceptical detachment: «Why, saw you anything more wonderful ?», «Indeed, it is a strange-disposed time; But men may construe things after their fashion, Clean from the purpose of the things themselves»; he is a rational man, and concedes that «this disturbed sky is not to walk in.» Cassius, on the other hand, under the same disturbed sky, works on Casca's vulnerable fantasy with more «instruments of fear and warning Unto some monstrous state.» Thus the play's Cicero diagnoses, and its Cassius manipulates, Casca's my thopoeic consciousness.

Throughout the play's first movement Shakespeare assimilates what North's margin calls the «Predictions and Foreshews of Caesar's Death» into the «ideot self», the private, phantasmagoric awareness of the conspirators. The catastrophic processes of the play are both publicly and intimately generated, the afflictions of the society have both a private and a communal pathology. "Since Cassius first did whet me against Caesar, I have not slept»; Brutus's insomnia reached Shakespeare as a matter of historical report: «care did wake him against his will when he would have slept.» Imaginative attentiveness to what North calls Brutus's «deep thoughts» helps to account for Shakespeare's quickening ability to move into obscure areas of human and verbal consciousness. The "phantasma» or «hideous dream» that troubles Brutus prefigures the 
tormented state-of-Scotland and state-of-mind that make Macbeth. The disarming truth that Shakespeare had no opportunity to read Freud should not prevent us from recognizing that Shakespeare's language has its own way of keeping in touch with what we now call the unconscious, while at the same time retaining its capacity to play upon the responses of a public audience. The Roman plays move across the territories of the community, the «self», and of the mediating language. Without attending systematically to the doctrines, if I may so call them, of Lacan, I would like to take advantage of a few of his formulations that have a bearing on Shakespeare's treatment of myth and history. Listening to Brutus's soliloquies or to Macbeth's, we have often reason to reflect that «the unconscious is structured like a language»; and keeping track of Brutus's exchanges with Cassius we can find our own reasons, if not Lacan's, for saying that «the unconscious of the subject is the discourse of the other.» ${ }^{1}$ Cassius's discourse is addressed to Brutus's unconscious; hence the obscure and private dispositions of the assassins assist in the determination of public events. They assist in creating an image, or a myth, of Caesar, and then they destroy it. "What private griefs they have, alas, I know not, That made them do it», is Antony's calculatingly guileless reflection. The play invites us to look for motives that are not objectively political. Cassius's memories of Caesar, for example, have a personal as well as a public significance (I.i. 90-131); and Brutus's ancestral consciousness (II.i. 46-58) is not transmitted through merely political channels. The conspirators are personal mediators of public consciousness, makers of my th and history: «the eye sees not itself But by reflection, by some other things.» While Cassius forges in Brutus's mind the Caesar «that bestrides the narrow world», the populace are clapping and hissing their festive hero as if he were a player in the theatre. Thus Caesar, the man of ordinary clay, grows prodigious in the acclaim of the rag-tag people and in the fears of the conspirators. Cassius both creates and uncreates the myth of Caesar, and it is apt enough that he should mythologise his personal relationship with Caesar by 
remembering Aeneas's rescue of Anchises - he finds a place for himself in the fabled history of Virgil's Rome (I.ii. $112-15)$. Shakespeare's theatre is revealing something of that process of screening which memories undergo both in the «single and peculiar life» and in the memorialising history of the state: ${ }^{2}$

Despite the glance at Virgil, however, the characteristic mode of fiction that shapes the catastrophic movement of events in Julius Caesar is not epical but tragical. The king-slaying is, in a range of senses, acted out and staged. Caesar in both Shakespeare's play and Plutarch's story, dies at the foot of Pompey's statue. Political history requires that the imperial spirit of Rome should erect such giant forms and that its republican spirit should pull them down. In personal and domestic perspective the imperial spirit looks like grotesque vanity and the republican one like emulous spite. From both political and intimate experience of the process of assassination, the history play is made for tragic theatre. The «history» and the «tragedy» are not co-extensive, and we are made to see that a disposition to make tragedy is part of the history.

Shakespeare makes no use of Plutarch's report that Romans made Caesar dictator because they hoped that to be «ruled by one man alone» would be «a good means for them to take breath a little» after the civil wars. On the contrary, he allows no scope for the judicial weighing of possibilities, and expresses its suppression through the conspirators' treatment of Cicero. "It shall be said his judgement ruled our hands», says Mettelus, «and all be buried in his gravity.» «Oh name him not», says Brutus, «let us not break with him» (take him into our confidence). The Roman community is therefore given over to irrational sacrificial practices and satisfactions that Shakespeare; no doubt with the assistance of Seneca, had taught himself to recognize as «Roman» in Titus Andronicus. Marcus Brutus sees himself as priest and Caesar as host ( Let us be sacrificers, but not butchers»); and Decius Brutus visits the mythopoeic dreaming consciousness of Caesar to persuade him that from him great Rome «shall suck revi- 
ving blood.» That final convulsion of adulation sends Caesar forth in the confidence of his own divinity. Marcus Brutus sees himself as saviour and priest in the eye of Cassius; Caesar takes himself for saviour and martyr in the eye of Decius Brutus. Since Brutus's «ideal itself» is generated from family tradition. («awake and see thyself») and since Caesar is aspiring to meet expectations that Pompey once satisfied, the convergence of their roles has a political as well as a private significance.

Caesar has a part to play in both Brutus's tragedy and Antony's ; but the assassination which is the climax of Brutus's tragedy is only a turning-point in Antony's. Antony's in-touchness with the driving motives of Roman consciousness is more profound than Brutus's, in ways that the play makes us understand, both through the character and persona of Antony and, more obliquely, through internal structural analogues which will respond to formal theatrical and political analysis. Antony makes his crucial appearance at the centre of the play, and he might be said to reverse its flow. Peripeteia, actual, imminent, or potential, is in this play a recurring structural device. I have suggested on another occasion that we can usefully borrow a phrase or two, and a certain disposition of mind, from catastrophe theory in mathematics. In the human world as in the mathematically describable one, incremental changes can have more than incremental effects; little-by-little they can bring human consciousness and behaviour into crises from which there is no little-bylittle recovery. One useful phrase is «divergence effect», describing what happens when the tracks of one of Thom's seven equations, shifting in one or more of its variables, carries it towards a sudden change of configuration. Julius Caesar has many such instabilities and divergences, when events, or our consciousness of them, could suddenly change direction : Caesar's refusal of the crown; the seduction of Brutus; the exclusion of Cicero and the sparing of Antony; Caesar's defiance of augury; the appeal for Cimber; the orations in the market-place; the murder of Cinna the poet; the quarrel between Brutus and Cassius; and 
the battle of Philippi itself. All these episodes are catastrophically poised before they are resolved. All may be said (from the evidence at Shakespeare's disposal) to convey historical truths; and all may be said to satisfy the laws of theatre (and therefore of fiction, and therefore of myth).

It is Antony's oration over Caesar's body that offers the keenest divergence-effect of the play. Antony's authentic grief is transmuted by theatrical art into political manipur lation, and the natural distress of the populace is perverted into communal savagery. Antony's mythopoeic skill finds starting-points in Plutarch as he takes, for example, «Caesar's gown all bloody in his hand»; and it embellishes his rhetoric with touches of what might be called «fictional fact» or screen-memories - «That day he overcame the Nervii», «See what a rent the envious Casca made.» But by this moment the damage has already been done, inflicted by an incremental rhetorical device : the eight-times repeated and finally dispossessed word, «honourable». The populace?now become indeed the «cruel men of Rome» Murellus saw in the first scene, will soon be lynching Cinna the poet. The «dogs of war» Antony lets slip are visceral reactions to Caesar «the bleeding piece of earth», sacrificed by Brutus in the fulfilment of his republican duty to his ideal self (his ego-ideal). Both Brutus and Antony bring about the catastrophes they affect to fear - each performs his tragic play. The deaths of Brutus and Cassius have a tragic significance in both the conspirators' play and in Antony's; but the battle of Philippi and emergence of the triumvirate reach us primarily as historical events in the continuing life of Rome.

It was a life, we may reflect, that in the history and in the theatre had to be carried on without Cicero. His judicious, attic good sense - the sort that might in the play. have come by the spirit of Caesar without the shedding of blood - is summarily disposed of : «Mine speak of seventy senators that died By their proscriptions, Cicero being one - Cicero one ? - Cicero is dead.» The historian Atticus, we may notice in passing, had by this time returned to Greece, where he was able to offer asylum to some of 
the victims of Antony's imperial affections. Cicero died a victim to the tragic sense of life, about which he wrote so teasingly in the dialogue of Brutus and which Brutus himself so fully embodied. "Which only goes to show», if I may again subvert Lacan, «that the offering to obscure gods of an object of sacrifice is something to which few subjects can resist succumbing, as if under some monstrous spell. $\rangle^{3}$

The Rome of Coriolanus is under a different spell, cast in a different Roman English. But this play too is highly conscious of the relationship between the processes of history and those of theatre, between annals and myths. Plutarch's story, to return to Cicero's phrase, gave Shakespeare ample chance for «rhetorical and tragic embellishment.» In a later passage of Brutus Cicero commends the rhetorical accomplishment of another Mark Antony the orator who died in $87 \mathrm{BC}$ as a victim of the Marian proscription. Cicero is finding Roman virtue in the close consonance of word and action :

If we divide delivery into gesture and voice, Antonius's gesture did not seek to reflect words merely, but agreed with the course of his thought - hands, shoulders, chest, stamp of the foot, posture in repose and in movement, all harmonizing with his words and thoughts; voice sustained, but with a touch of huskiness. This defect, however, he had the skill to turn to advantage... You can see how all this bears out the saying attributed to Demosthenes who, when asked what was first in ortatory replied «action», what second, «action», and again what third, «action». Nothing else so penetrates the mind, shapes, moulds, turns it, and causes the orator to seem such a man as he wills to seem. (142)

Penetrat in animos, fingit format flectit, qualis ipsi se videre volunt : the Latin phrases might well evoke the language and gesture of Shakespeare's Coriolanus, the play 
and the man. Fingit format flectit; language (again I concur with Lacan) ${ }^{4}$ is not a sign, and at its most fully active it does more than communicate; it makes. It informs and shapes a man as he wills to seem, and it penetrates in animos:

$$
\text { you may as well }
$$

Strike at the heavens with your staves as lift them Against the Roman state, whose course will on The way it takes, cracking ten thousand curbs Of more strong link asunder than can ever Appear in your impediment.

That is the state embodied in Caius Martius, rhetorically at the disposal of his surrogate father, Menenius. But three bodies-politic make the Roman scene : one with fat enough upon it to make the belly smile - rhetor and politic survivor; another erect, rigorous, invincible - the state warrior in the warrior state; and the third «the beast with many heads», the «voices», «rubbings the poor itch of their opinion to make themselves scabs.»

The language and spectacle of the theatre create from the metaphor of the «body-politic» a range of impacts and effects quite out of reach of the narrative sources and reflective analogues (in John of Salisbury, for example). Shakespeare's abilities as a poet are fully engaged in creating those responses to language that are most intimately related to the warrior cult of the body. We are at verbal risk if we call the playwright's art in this mode «mythpoeic»; yet it is so if it is more fully realising the potency of a fiction that has great significance for the state. As Cominius says of Martius when he leads the Volscians against Rome, «He is their god; he leads them like a thing Made by some other deity than Nature, That shapes men better.» If we ask what desires are satisfied and what values articulated by Martius's heroic drives, the responses we get from the play are political, but not merely political; and they are Roman, but not merely Roman. In the history of the unified, heroic state, we recognize the dependence 
of the city upon Martius for its continuing life and identity. Were he not shaped better than other men, the battles for Corioles would have been lost (Cominius's temperate virtues could not have won it), and Rome would have undergone the subjugation and dissolution that the Volscians suffer at the end of Plutarch's story. In the history of the divided, multiple community, however, those same heroic drives are activating a malignant class war between (there are many ways of putting it) «Rome and her rats», the eaters and the eaten, those who «run reeking o'er the lives of men» and the "quarter'd slaves.»

The play's more intimate structure offers analogous antinomies, the brutal street and battle-field confrontations transposed into a cultivated domestic retreat. Yet here, it may be claimed, is the genesis of the warriormyth-of-state : «If my son were my husband», says Volumnia at the scene's start, "I should freelier rejoice in that absence wherein he won honour than in the embracements of his bed where he should show most love ; and a few moments later she visibly and audibly rejoices as if her son were indeed her husband :

Methinks I hear your husband's drum;

See him pluck Aufidius down by th'hair,

As children from a bear, the Volsces shunning him.

Methinks I see him stamp thus, and call thus : «Come on, you cowards, you were got in fear Though you were born in Rome !» His bloody brow

With his mailed hand then wiping, forth he goes Like to a harvest-man that's task'd to mow Or all, or lose his hire. (I.iii. 29-37)

Volumnia's is the voice and language, as well as the «honoured mould», that bred Martius and brought him into the world, better shaped than other men, to sustain a warrior-caste society that evidently (we learn in passing) treats its harvest-workers pretty rigorously. The war-delight 
is sexually informed, the language creating vicarious battleexcitements more satisfying than remembered «embracements» of a dead husband's bed. But that war-delight, as Shakespeare had reason to know, has a more spacious history than Volumnia's widowed state affords it. He glances back to Homer's Troy, culls material from Elizabe than classical literature of Sparta, and keeps a close watch on his Jacobean audience's readiness to make idols, both in the theatre and in the streets, of men of blood, whether fact or fiction, long dead or still alive. Plutarch's Moralia includes a story about a Spartan mother proclaiming her sons finer pieces of work than the most costly and curious piece of tappestry. Volumnia thus flaunts her son and her grandson, to Virgilia, silent at her embroidery. In the warrior-state the husbands die in battle and sons displace them, and the widowed mother must find her sexual joy, her jouissance, in her vicarious, language-shaped ecstasy of battle (penetrat in animos, fingit format flectit . . .). Cominius's great oration («the deeds of Coriolanus Should not be utter'd feebly") is largely made from the words of North; but, coming upon it fresh from Volumnia's cruel raptures («The breasts of Hecuba When she did suckle Hector, look'd not lovelier Than Hector's forehead when it spit forth blood»), we pick up the subliminal sexuality and seem to know why Tullus's rapt heart dances when he embraces the body that has so often splintered his grained ash. It would be possible to evoke more significances from the language and the latencies of our awareness, from the gates of Corioles «bringing forth» their youth, to the "lonely dragon in the fen» come to ravish the daughters of Rome, and to the father wishing his son to «stick i'th'wars Like a great sea-mark, standing every flaw and saving those that eye him.» Those darknesses of the mind are more searchingly explored in Macbeth where Murder «with Tarquin's ravishing strides» moves like a ghost; and more directly in The Rape of Lucrece where Tarquin extinguishes the light before his «proud flesh» metaphorically batters down the consecrated walls of the city. (I break off, before exposing my 
own unconscious to diagnostic inquisition).

I have concentrated on some of the energies and structures of two plays, with the intention of relating instabilities of the Roman state to persisting, if not perennial instabilities of human consciouness, the sort that might still find life-transcending virtue in contempt for life, in the heroic service of the community. I am tempted to say that the state-of-the-state is matter of history, and the state-of-consciousness matter of myth. But the words «myth» and «history» never have stood still and never will - they will continue to run up and down and in and out on a great diversity of errands. I'll keep them at heel long enough, however, to let them say that Shakespeare the playwright, poet and historian, simultaneously exploring and celebrating states-of-mind and minds-of-states, makes historical myths of lasting significance.

Yet let me deny myself that rhetorical coda and re-open the box I pretended to close. The term «historical myth» is often used about fictions that are felt to be useful in the interpretation of history. Coriolanus is in this sense too a historical myth. The historian J. B. Black, writing on The Reign of Elizabeth in 1936, tells us that the queen was «little likely. . . to entrust the destiny of the state» to the Earl of Essex, "a man whose genius shone on the battle-field, and not in the counsels of peace.» «The earl», he says, «could not change his nature. He could not school his imperious mind to the give and take of politics, or share responsibility at the council table.» He could not move «from the casque to the cushion»; Professor Black is writing Aufidius's history of England. Perhaps his responses had been tuned by Lytton Strachey who, in Elizabeth and Essex, commends the General of the Horse at Zutphen for giving «all men great hope of his noble forwardness in arms»; but commends the queen for succeeding «by virtue of all the qualities which every hero should be without - dissimulation, flexibility, independence, procrastination, parsimony.» I am not re-issuing that old invitation to «identify» Shakespeare's great warriors with Essex, but recognizing that Coriolanus brings to a climax 
that conflict of values which persisted through Shakespeare's lifetime in the court and city with which he was acquainted, between «noble fowardness» and «dissimulation». Both «nobility» and «dissimulation» change their meanings in Antony and Cleopatra, and rhetorical tactics must allow it a mere postscript on the ground that it is not only a Roman play but also an Egyptian one. It is also a different kind of «myth». In the course of resolving the historical and political tensions of the Roman Empire into a unified experience of the affections, Shakespeare calls upon the arts of rhetoric and on the myths of Isis, Dionysus, Venus and Mars. When Antony says, «Unarm Eros, the long day's task is done, And we must sleep», Shakespeare takes the chronicled name (Eros) into a pagan mystery of the renaissance - Mars is again disarmed by Venus. When Cleopatra says, «His legs bestrid the ocean», Shakespeare and she are making myth out of history; for what cannot be true of Antony's legs ( «gentle madam, no») is true of Roman arms; love, like the empire, is required to span the Mediterranean. 
NOTES

1. Jacques Lacan, Ecrits, A Selection, trans. Alan Sheridan, Tavistock Publications, London, 1977, p. 55.

2. I borrow the term «screen memories》 here and elsewhere from the psychoanalysts. Re-creative fictional distortions of memory occur both in the individual's history and in that of the state (which does not always write its annals true - Cor. v.vi 113). Renaissance theories of history as an analogue of memory respond usefully to this sophistication. See also Lacan, Ecrits., p. 47.

3. Lacan, The Four Fundamental Concepts of Psycho-Analysis trans. Sheridan,1977, p. 275.

4. Lacan, Ecrits, p. 83. 